inOedia $\quad \begin{aligned} & \text { InMedia } \\ & \text { The French Journal of Media Studies }\end{aligned}$

$1 \mid 2012$

Global Film and Television Industries Today

\title{
Sharing the Joke? 'Britcom' Remakes in the United States: A Historical and Socio-Cultural Perspective
}

Amandine Ducray

\section{(2) OpenEdition}

Journals

Electronic version

URL: http://journals.openedition.org/inmedia/132

DOI: 10.4000/inmedia.132

ISSN: 2259-4728

Publisher

Center for Research on the English-Speaking World (CREW)

Electronic reference

Amandine Ducray, «Sharing the Joke? 'Britcom' Remakes in the United States: A Historical and SocioCultural Perspective », InMedia [Online], 1 | 2012, Online since 23 March 2012, connection on 07 September 2020. URL : http://journals.openedition.org/inmedia/132 ; DOI : https://doi.org/10.4000/ inmedia.132

This text was automatically generated on 7 September 2020

(C) InMedia 


\title{
Sharing the Joke? 'Britcom' Remakes in the United States: A Historical and Socio-Cultural Perspective
}

\author{
Amandine Ducray
}

1 Since the publication of Herbert Schiller's Mass Communications and American Empire in 1969, theories of North American 'cultural imperialism' have been seminal in the fields of transnational broadcasting and cultural studies. As Jeffrey Miller underlines, however: "At the very moment Schiller was identifying [...] the role of American media in creating 'its emergent imperial society,' the domestic producers and consumers of those media were themselves experiencing a new flow of messages and texts from Britain." In 1964, NBC blazed a trail when it remade the BBC satirical show That Was the Week That Was (1962-63). ${ }^{2}$ This was soon followed by another 'entertainment' transfer, the Bond-inspired series The Avengers (ITV, 1961-69), broadcast on ABC (1965-69) in its original version, and, a few years later, by All in the Family (CBS, 1971-79), adapted from Till Death Us Do Part, launched on BBC1 in 1966. The latter represented a further landmark in television history; it was the first British sitcom-or 'Britcom' as they are called in the United States-to be remade for American viewers. ${ }^{3}$

2 As illustrated here, in the US, British formats can either be broadcast in their original versions or retooled to meet an American audience's tastes and expectations. Regarding comedy, the alignment of 'encoding'-i.e. how messages are produced by the television institution-and 'decoding'-how they are received-appears paramount given the idiosyncratic nature of humour. ${ }^{4}$ For if joke-telling implies a tacit 'contract,' situation comedy, through 'canned laughter' and constant repetition, tends to institutionalise such community bonding. This must be the reason why most American mainstream broadcasters choose the remake option. Due to national specificities in terms of characters, settings and cultural references, as well as to the general feeling of shared knowledge conveyed in British sitcoms, these are often precisely deemed 'too 
British' by American viewers, not to mention the accent, which, though sometimes a selling point, may also deter some from watching a programme. ${ }^{5}$ All elements therefore need to be adapted, or 'Americanized,' for viewers to be able to share the joke. 'You can laugh about everything," French humorist Pierre Desproges once said, "but probably not with everyone," he added. ${ }^{6}$

3 Following a historical approach, in this article, I shall first examine the birth of situation comedy in the US and in Great Britain. After observing how different types of humour have been constructed, I shall study what motivated American producers to adapt 'Britcoms' from the 1970s onwards. Through a sample of case-studies, this development should allow me to map out what determined the success, or failure, of these remakes, before moving on to the latest hit in such cross-cultural translation, the NBC version of the BBC's The Office.

\section{American and British situation comedies: contrasted origins (1930s-1960s)}

4 Coined in the United States in the 1930s, the term 'situation comedy' was first applied to Amos 'n' Andy, launched in 1926, on a Chicago radio station-originally as Sam 'n' Henry -and brought to television by CBS, in the early 1950s. Following the tribulations of two African-Americans who had moved from Atlanta to Chicago, the programme was influenced by sundry forms of contemporary entertainment, including minstrelsy, slapstick, and variety theatre. Another influence was newspapers comic strips, such as The Gumps (1917-59), from which Freeman Gosden and Charles Correll, the scriptwriters of Amos ' $n$ ' Andy, were specifically asked to draw their inspiration. ${ }^{7}$ Based on a short narrative structure with little plot development allowing the weekly repetition of a fixed situation, comic strips were a formidable asset in building up audience loyalty. The technique was then replicated on the radio, where Amos ' $n$ ' Andy itself was designed as 'appointment programming,' i.e. "a show around which families tended to structure their domestic arrangements [so as not] to miss an episode." ${ }^{8}$ As such, the series soon caught the attention of sponsors, notably Pepsodent, which used the black heroes' smiles as a foil for its dental hygiene products.

5 In turn, the advent of television in the 1950s boosted the commercial value of sitcoms as American households were increasingly seen as HUTs ('Homes Using Television') and viewers as consumers. On moving to the small screen, the genre underwent two changes, in terms of format and situation. To this day, the length and time slot assignment of sitcoms are strongly codified; most are weekly half-hour programmes broadcast prime-time and the plot is written to run a total of 22 minutes in length, leaving 8 minutes for commercials. As for the situation, tying the new medium to advertising produced a focus on middle-class domesticity; the decade saw the birth of 'dom-coms' and of the archetypal "WASP sitcom family." The Burns and Allen Show (CBS radio and TV, 1936-58) and My Favorite Husband / I Love Lucy (CBS radio, 1948-51; CBS $\mathrm{TV}, 1951-60)$ were exemplary in this respect. The latter even served as a template for the genre on television; the first to be shot in front of a studio audience, whose reactions were recorded as a 'laughter track,' it also pioneered the use a three-cameraset-up-a technique still central to most sitcoms. 
6 Meanwhile, in Great Britain, the BBC's monopoly had created a completely different landscape. Initially established as a state-funded body, the BBC did not carry advertising, as the 1923 Sykes report had made clear. ${ }^{10}$ Moreover, under the longlasting Directorship of John Reith (1922-38), it was committed to 'Public Service Broadcasting' through a tripartite mission "to inform, to educate and to entertain." Comedy consequently came last on the list of priorities of the BBC, which, in the early years at least, tended to equate entertainment strictly with light band music. During the Second World War, however, British listeners enjoyed more and more European stations like Radio Luxembourg and Radio Normandie, which did not hesitate to tap into American-style entertainment. Combined with John Reith's departure from the BBC in 1938, such competition fostered the appearance of the proto-sitcoms Mr. Muddlecombe, JP (1937-53), starring Robb Wilton, and Band Waggon (1938-39), in which Arthur Askey and Richard Murdoch played an eccentric couple living on the roof of the "Broadcasting House,' i.e. the official headquarters of the BBC. First influenced by music hall, where their comedians came from, over the years, both shows gradually abandoned the variety model to embrace a US-inspired sitcom format. The same can be said of It's That Man Again (1939-49), the first deliberate attempt "to produce British programmes with American-style quick-fire patter,"11 and of Life With The Lyons (1951-61), which, like The Burns and Allen Show, for instance, featured real-life couples of comedians in a domestic environment.

7 In both countries, the advent of television thus marked a turning point in the history of a genre imported from the US to Great Britain. Yet, at the same time, the decade saw the birth of two distinctive types of sitcom humour: "If I Love Lucy represented a defining moment in US sitcom, Hancock's Half Hour [BBC radio \& TV; 1954-61] [...] played a similar role in the UK. The programme, scripted by Ray Galton and Alan Simpson and starring Tony Hancock, adopted the domestic setting of its contemporaries but was marked by a decisive shift away from gag-based humour towards character and environment as the defining features of its comedy." ${ }^{12}$ Casting regular actors instead of music hall or stand-up comedians indeed exemplified a change from both US and British comedies. From then on, in Britain, the emphasis was less on fast-paced comedy, songs and wisecracks, than on the sometimes static observation of life with a socio-realistic perspective.

8 In Hancock's Half Hour, Tony Hancock played a down-at-heel actor living at 23 Railway Cuttings, East Cheam, a place regularly depicted as a council house (a form of social housing). From his position on the margins of society, the character occasionally commented on the political realities of life in Britain, including the 1956 Suez crisis and the railway strikes of the 1950s and 1960s. The feeling of thwarted upward mobility conveyed by this dysfunctional 'hero' thus stood in sharp contrast with its US counterparts, which, given the commercial structure of radio and television, were rather "committed to harmony and consensus." 13

9 Retrospectively, a second influence of Hancock's Half Hour in Britain is the use of a limited number of scriptwriters, one or two, contrary to the United States, where most sitcoms are still based on team or table writing. Famous British names include Dick Clement and Ian La Frenais, notably with The Likely Lads (BBC2, 1964-66), which presented two Northern blue-collars; Johnny Speight, with his working-class bigot Alf Garnett, in Till Death Us Do Part (BBC1, 1966-68; 1972-75); and Ronald Wolf and Ronald Chesney's workplace sitcoms, including On the Buses (ITV, 1969-73). Following Hancock's 
show, Ray Galton and Alan Simpson themselves collaborated on Steptoe and Son (BBC, 1962-65; 1970-74), itself based on a very down-to-earth, prosaic situation, that of two hapless rag and bone men, father and son, stuck in Shepherd's Bush, London.

10 Contemporary to the appearance of 'kitchen sink' dramas, the emergence of workingclass sitcoms was somehow emblematic of Hugh Greene's BBC Directorship (1960-69). ${ }^{14}$ Facing competition from ITV-the first British commercial network, created in 1954 to promote regional specificities-Hugh Greene encouraged a spirit of 'mischief' on the channel. But apart from its broadcast on 'Auntie Beeb,' such material was actually nothing new to the British public. From the comic strip drunkard Ally Sloper (1884-1923), to the saucy post-war postcards of Donald McGill and the long-running Benny Hill Show (BBC/ITV, 1955-89), Britons had long been enjoying this quintessentially British mix of social satire and broad farce. ${ }^{15}$ Yet, for all their British traits, two of the most popular working-class sitcoms of the time were soon exported to the US.

\section{Exporting 'Dear Old Blighty' to across the pond: from 'special relationship' to 'dangerous liaisons' $(1970 s-1990 s)^{16}$}

11 In May 1961, Newton Minow, the Federal Communications Commission Chairman (1961-63), made a speech to the National Association of Broadcasters which was a turning point in US television history. Decrying the lack of overall quality in the American broadcasting landscape, he famously described it as "a vast wasteland," calling for an alternative, free from advertising, and with a mission to uplift, rather than distract, masses. From then on, "national intervention in television [was] spurred by the realization that 'Americans were making an enormous mistake to let the law of the least common denominator set the sights of broadcasting." 17 Launched in 1970, the Public Broadcasting Service aimed at balancing a generally consumerist 'mass' culture with BBC-inspired 'quality' programming. Indeed, one of the first shows PBS aired was an adaptation of The Forsyte Saga (BBC2, 1967), a historical drama based on John Galsworthy's novels. Though criticized for appealing mostly to high-brow audiences, the new service had opened a debate on the role of American television.

12 This debate must have been closely followed by US comedy writer, director and producer Norman Lear, who began his career in the mid-1950s, when home-made 'domcoms' were thriving. A decade later, Norman Lear, also a civil rights movement activist, was calling for a more realistic portrait of American society on television. Taking the opposing view of PBS elitist programming, in 1971, he tried to sell the idea of a bluecollar sitcom to $A B C$, which rejected it, arguing it would not suit its viewers' tastes. Norman Lear then changed strategy and approached CBS with an adaptation of Till Death Us Do Part (BBC1, 1966-68; 1972-75).

Besides being able to watch footage of the sitcom, what prompted CBS into giving him the go-ahead was its large success in Britain; five weeks into the first season, the series had already toppled its competitor in the viewing ratings war, the soap opera Coronation Street (ITV, 1960- ). Last but not least, its lower-middle-class environment provided a new means of entering the marketplace. The deal proved a winning bet: All in the Family (CBS, 1971-79) reaped the Prime-Time Emmy Award for Outstanding Comedy Series in 1971; it ranked number one in the viewing ratings five years in a row, 
and resulted in three CBS spin-offs, Maude (1972-78), The Jeffersons (1975-85), and Archie Bunker's Place (1979-83).

All in the Family is an interesting case of "absorption and domestication." 18 As obvious in the title, CBS preferred to promote a familiar format-domestic comedy-than to appeal to the public with the feeling of entrapment and social satire conveyed in the original. From the British series, though, Norman Lear kept the truculent holier-thanthou father figure. Like the character Alf Garnett, Archie Bunker was a loud-mouthed racist and sexist bigot who regularly insulted his wife. Yet by adding "cultural elements with embedded significance" to the plot, the writer skilfully assimilated the British working-class situation and tailored it to match American norms and beliefs. ${ }^{19}$ This included transposing Canning Town, in the East End of London, to a similar postindustrial and minority-populated area, the Astoria section of Queens, New York City, and turning the Tory cockney football fan into a Republican soccer lover. More importantly, in both versions, the father systematically opposed his more left-wing son-in-law. Together with a blue-collar environment, the narrative pattern repeated a 'comedy of frustration' central to many British situation comedies of the late 1960s, while giving a US sitcom an unprecedented political dimension. All in the Family discussed a whole range of controversial contemporary issues, including the Vietnam War, women's rights and race relations.

15 Over the course of its second season, Norman Lear decided to develop the race relations theme by adapting a second 'Britcom,' Steptoe and Son (BBC, 1962-65; 1970-74). In Sanford and Son (NBC, 1972-77), he used the same ingredients as in his first remake, i.e. transposing foreign cultural motives into local ones to produce an endemic situation. A significant novelty was introduced: the white English junk dealers had become African-Americans. The choice seemed to imply certain limits in humour transferability: "In the English version the father is very caustic, almost vicious. For a lot of reasons we didn't think that attitude was right for [comedian] Redd Foxx, so we made him gentler." ${ }^{20}$ Besides the sardonic nature of the white hero, what appeared problematic must have been the 'situation' chosen as the US programme was released only a few years after the 1964-67 summer race riots, which had started in Harlem, New York City, and in the Watts neighbourhood of Los Angeles, where the fictitious Sanfords themselves lived. Following the troubles, the Kerner Commission was appointed to investigate their causes; published in 1968, its report mentioned the responsibility of television, especially of the news, in black rebellion. ${ }^{21}$

16 Pronounced a year after Sandford and Son's final season, Norman Lear's keynote address at the 1978 Edinburgh International Television Festival seems enlightening in that respect: "Those programmes which do not deal with the real problems of life [...] are, by omission, saying: 'You have no race problems; there is no economic concern in the nation, we are not in trouble in Vietnam; everyone does have an equal crack at medical attention; there are no problems with the poor or elderly or the uneducated-and all mothers and fathers and children live in absolute harmony." ${ }^{22}$ Well-received in Britain, this statement came as a blow to the somewhat happily-ever-after vision of most contemporary US sitcoms.

17 But even if his adaptations fostered sitcoms with a woman's or a black perspective, The Mary Tyler Moore Show (CBS, 1970-77) or The Cosby Show (NBC, 1984-92), for instance, remained committed to a classic conception of the genre, both in their titles and in the celebration of shared family values. Twelve years after Sanford and Son was launched, 
the latter was its exact opposite: the Huxtables' brownstone in Brooklyn Heights highly contrasted with the scruffy Watts dwelling of the Sanford junk dealers, as did their professions - the father was an obstetrician; the mother an attorney. ${ }^{23}$ Again partly implied by the commercial structure of American network television, the commitment to the preservation of the 'American Dream' seems to have accounted for such sociocultural differences between US and British comedy.

18 In Britain, meanwhile, the incessant viewing ratings battle between BBC and ITV to reach a mass working-class audience had produced such sitcoms as Are You Being Served? (BBC1, 1972-85) and Man About the House (ITV, 1973-76), which gradually abandoned socio-realism for ribaldry. Key to the popular Carry On film series (1958-78; 1992), such comedy expectedly entailed the casting of buxom 'dolly-birds'. As for US commercial networks, following Norman Lear's success, they were now seeing great potential in 'Britcoms' and Man About the House even led to a tug-of-war between ABC and CBS. Eventually broadcast on ABC, Three's Company (1977-84) ranked second twice in the yearly viewing ratings, and led to several spin-offs. Penned and produced by Don Nicholl, Michael Ross and Bernie West, who had worked on All in the Family, the series was but loosely based on the original. Being quite basic-a young man shared a flat with two single female students-its situation was easily transferable and, besides the United States, it was remade in the Netherlands, Poland, in Norway and in Sweden. Though still echoing changing global cultural trends, including cohabitation before marriage, like in Britain, the American sitcom mainly appealed to the 'average viewer' for its ongoing sex plots and for Chrissy, a sexy, ditzy blonde.

19 Looking at successive remakes, Three's Company nevertheless seems to have somehow tolled the knell for 'Britcoms' in the USA. Are You Being Served? (BBC1, 1972-75) was adapted too, by the English writers themselves, David Croft and Jeremy Lloyd, as Beane's of Boston. Aired on CBS in 1979; its pilot never developed into a full series. The original, however, was shown on PBS, along with Fawlty Towers (BBC2, 1975; 1979), a US adaptation of which has been attempted thrice so far, in 1978, 1983, and in 1999. As for the NBC remake of the self-explicit Men Behaving Badly (ITV/BBC1, 1992-98), it was dropped in 1998, after just one season, which led the newly-launched BBC America to broadcast the original. Similarly, Absolutely Fabulous (BBC2, 1992-96), aired on BBC America and Comedy Central, has known an 'absolutely disastrous' fate as an adaptation. Roseanne Barr bought the rights in the late 1990s; not even a pilot was shot. A decade later, in 2009, Fox announced another attempt. As the original's executive producer Jon Plowman had predicted, dropping the characters' drinking, smoking, and swearing habits-deemed too controversial for an American audience-crucially deprived AbFab of its comic raison d'être. ${ }^{24}$ Having shared a similar experience with Men Behaving Badly US, British producer Beryl Vertue explains that, from the 1990s onwards, the rejection of 'politically incorrect,' or un-PC, contents has led Britain to turn to other, mainly European, partners, like Germany, Poland or Italy, instead of the US. ${ }^{25}$

20 Combined with increased accessibility to the originals on alternative channels, this diverging conception of comedy, of offensiveness and decency, undoubtedly accounted for the remake flops of the 1980s and 1990s. A decade after Norman Lear had started remaking 'Britcoms,' the "absorption and domestication" of British situation comedies now seemed doomed to fail. ${ }^{26} \mathrm{~A}$ third reason must have been the success of innovative home-made productions like Cheers (NBC, 1982-93), shot in a Boston bar, and spin-off Frasier (NBC, 1993-2004), but also of blue-collar sitcoms, like Roseanne (ABC, 1988-97) or 
the animated The Simpsons (Fox, 1989- ). Over the decades, US professionals had thus not only moved away from the conventional 'dom-com' of the 1950s and the 'Britcom' remakes of the 1970s and 1980s, they had learnt to copy a foreign programme and turn it into a genuinely American one.

\section{Global perspectives and local idiosyncrasies in the twenty-first century: the case of The Office (BBC2, 2001-2; NBC, 2005- )}

21 Several 'Britcoms' had been tentatively remade in the United States at the turn of the century, including The Royle Family (BBC1, 1998- ), as The Kennedys (CBS, 2001), or the eponymous Coupling (BBC2, 2000-4 / NBC, 2003). Again, all failed, continuing to reveal clashing perceptions of propriety. Commenting on a clean-up trend increasingly known as 'pasteurization' in the US television and film industry, Maya Forbes, the head writer of The Kennedys, explained: “You can't even say 'Jesus Christ!' on American network TV. There's smoking only if one of the characters makes a responsible comment about how bad it is. [...] We also have to think of a replacement for Jim's 'my arse' catchphrase. It's difficult to find something with bite that you can actually say." ${ }^{27}$ Given such politically correct television environment, NBC's launch of The Office, in 2005, could have been either a breakneck decision or a bold one.

Created, written and directed by Stephen Merchant and Ricky Gervais, who also played the main character, The Office (BBC2, 2001-2) was as much a 'mockumentary', i.e. a 'mock-documentary,' as a sitcom. ${ }^{28}$ Despite the "circular narrative closure" emblematic of the genre-meaning every conflict was solved as the episode ended-the fly-on-thewall approach entailed the absence of any studio audience or laughter track, and the replacement of a generic triple-camera-set-up with a single, hand-held, one ${ }^{29}$ Like in a documentary, editing was slow-paced and included blank stares or direct glances at the camera. As Ricky Gervais explained, reality-TV was a further influence on this hybrid format, which incorporated talking-head interviews, or 'confessionals'. ${ }^{30}$ Its situation was simple: The Office follows the 9-to-5 lives of the employees of Wernham Hogg, a fictional mid-sized paper merchant based in Slough trading estate, in the South East of England, focusing on general manager David Brent (Ricky Gervais), who considers himself as "a boss first, a friend second, and probably an entertainer third," where he is in fact ignorant, rude and not funny-at least to his employees. The deadpan humour of the show proved a hit. The 2003 'Christmas Special' recorded a 30\% audience share with 6.5 million viewers and The Office not only won three British Academy of Film and Television Arts (BAFTA) awards in three years, but also-through BBC America in 2004two Golden Globes for 'Best TV Series: Musical Or Comedy', notably outranking Sex and the City (HBO, 1998-2004).

23 A year later, Ricky Gervais and Stephen Merchant met NBC for an adaptation. Covering a vast range of work-related topics, the original used situations that had been experienced by the 'global' public, either directly or by proxy. Thus easily exportable, besides the United States, the BBC series was remade in Canada, in France and Germany, but also in Brazil, Chile, Russia, and in Israel. In the US, while the British creators acted as executive producers, the remake was developed, and occasionally directed, by Greg Daniels and penned through table writing. Despite good ratings on its 
début on NBC-11.2 million viewers-The Office US pilot was thrashed by critics for being "a passable imitation of a miles better $\mathrm{BBC} .{ }^{31}$ In turn, ratings dropped to 5.4 million viewers for the first season and it was not until season two that the show found a sustained audience of 8 to 9 million. Meanwhile, it had found its own style too, less of a mock-documentary and more of a workplace sitcom.

24 Like Norman Lear's adaptations in the 1970s, The Office US integrates cultural references; the firm has for instance been transposed to Scranton, Pennsylvania, itself on the outskirts of the buzzing capital, and the show discusses the 'issues of the day,' which, in twenty-first century corporate America, include 'Sexual Harassment,' 'Performance Reviewing,' and 'Business Ethics,' to give but a few episode titles. In 2006, only two years after Ricky Gervais had received his Golden Globe, Steve Carrell, who played the American boss, received the same award, for the same programme, in its US version.

25 Away from an extensively verbatim pilot, the second episode, 'Diversity Day,' already suggested the retooling central to season two. Interestingly enough, its situation overlapped a theme developed in the $\mathrm{BBC}$ version-race relations. But where the latter focused on David Brent's latent racism; the NBC adaptation explored diversity in the workplace, a topic which, in the United States, had been given greater attention with the 2002 No-FEAR Act (the Notification and Federal Employee Anti-discrimination and Retaliation Act). A classic example of the English boss crossing the line is to be found in episode 1 , series 2 , which attracted the most viewers' complaints about the programme. The issue was a sequence known as "the black man's cock joke" and which involved Camilla Parker-Bowles and the Queen. Having heard the joke from his assistant Gareth, David Brent shares it with his employees only to freeze mid-sentence when a black man walks within earshot. When the latter recognises the joke, adding he thinks it is funny, the boss concludes: "harmless, well done!", then, in an attempt to change subject, David Brent turns to a wheelchair-bound female employee and asks: "Have you met this little lady?", plunging even deeper into un-PC talk. Following David's blunder, his supervisor Jennifer has a private conversation with him and concludes on a very pragmatic note: "You could save this joke for your free time and not say it in the workplace." In a single five-minute-sequence, the notorious joke has been shared twice with the public, widely circulated among the characters, and its title repeated ad nauseam. Meant to denounce racism in a humorous way, this 'in-your-face' approach was obviously not appropriate for American network television, which, since the advent of Political Correctness, was treading cautiously on such potentially offensive ground. Though also discussing race relations, The Office US's 'Diversity Day' indeed opens under completely different circumstances: Michael Scott's impersonation of black comedian Chris Rock having precisely stirred up a controversy, the whole team has to follow a seminar on diversity and racial tolerance in the workplace. Whereas management did not take any measure against David Brent, the US remake thus brings diversity policies into the centre of the episode. Considering himself as "The World's Best Boss," Michael Scott insists on coaching his team himself, only to prove his incompetence. Assigning each staff member a post-it note with a different race, he then launches a role-play: "I want you to treat other people like the race that is on their forehead," which, of course, produces the exact counter-effect of discourses on tolerance. Similarly to the BBC episode, much fun is derived from the presence of a black man, Stanley, who incidentally picks up the "Black" card. As opposed to the 
British joke, however, the character serves to illustrate the absurdity of ethnic stereotypes, not a bawdy, possibly offensive, comedy. Being bound to trigger a series of prejudices, the sequence even introduces a very 'politically correct' statement. When questioned by a colleague, Pam, the receptionist, declares: "Okay, if I have to do this. Based on stereotypes that are totally untrue and that I don't agree with [...]". While pointing, again, to the absurdity of the situation, the answer also anticipates potential viewers' complaints. The reaction of a South Asian-American woman who ends up slapping her boss in the face for his vision of her 'community', i.e. cookie-shop owners with a thick accent, obviously serves the same end. Contrary to that of the BBC episode, this closing scene shows that in the US, such comments are neither "harmless" in the workplace nor on television.

27 In The Office US, adapting to tastes of decency has further been accompanied by an aesthetics change. By opting for opening credits, NBC first explicitly revealed the fictional nature of the programme, as opposed to the $\mathrm{BBC}$, where leaving them until the end was a token of its supposedly documentary quality so that viewers might take the series at face value. To avoid "generic discomfort" for an American audience, Greg Daniels even doffed some of the original mockumentary elements, such as the dim-lit setting: "In the British version [...] they made some decisions to really go very bleak with the production [...] and it matched what they were trying to do which was to be very satiric [...]. We had an aim to be more of a character comedy," he declared. ${ }^{32}$ Dating back to the television developments of US and British sitcoms in the 1950s, the distinction already noted between 'satire' and 'character comedy' therefore still appeared paramount to The Office. Commenting on the two traditions, Ted Harbert, then President at NBC Studios, indeed explained that "the smaller and smarter joke[s]" had to be replaced with "bigger and more obvious comedy." ${ }^{33}$ Casting gagman Steve Carrell as the American boss undoubtedly contributed to replacing a satirical look on a static, dull office life with fast-paced slapstick comedy.

28 A third change occurred on a narrative level: whereas the original ran for two sixepisode seasons (2001-2), the US version has approximately 25 episodes per season, and NBC is currently working on the seventh. As for episode length, The Office US has produced what, from food to television, appears like a local idiosyncrasy: regular 40minute 'supersizes', twice the length of any BBC episode apart from 'Christmas Specials'. Generic to American television programming, such difference in format implied more character development in the US version. As in drama series, writers developed secondary characters from one season to the next, or introduced new ones, as in a real office. Similarly, to ensure plot longevity, love relationships between employees, including Jim and Pam-a transposition of Tim and Dawn-were given greater attention than on the BBC. As in soap operas, Jim and Pam's first kiss is for instance constantly postponed in the early seasons, which creates suspense meant to keep viewers tuned in. By retooling The office both culturally and generically, aesthetically and narratively, Greg Daniels has thus managed to create what reviewers eventually praised as "that rarest of anomalies: a remake of a classic show that both does right by its source and carves out its own strong identity." ${ }^{34}$ Though born in the United States, in the 1930s, and exported to Great Britain, the situation comedy genre has therefore experienced a long history of adaptations from Britain to the US. The launch of ITV, the first British commercial and regional network, in 1954, marked a turning point in that respect. Its influence was felt not only at home, 
where it contributed to the development of working-class sitcoms, including on the $\mathrm{BBC}$, but also across the pond. Following the debate on the role of national television in the US in the early 1960s, a decade later, American producer and comedy writer Norman Lear pioneered the adaptation of blue-collar 'Britcoms'. While remade to match an American audience's expectations, especially in terms of environment and cultural references, and to echo the US political issues of the time, his comic productions were the first to discuss what he considered as "real problems" and to propose a socio-realistic perspective clashing with the oft-idealistic 'American Dream' representation of most contemporary US situation comedies.

With increased access to the originals on PBS and on digital channels, however, the 1980s and 1990s put a hold on 'Britcom' adaptations. Given the appearance of 'Political Correctness' in the United States in the late 1980s, the contemporary rise of 'politically incorrect' British sitcoms further hindered their transferability to American network television, thus dramatically changing industrial relations between both countries. Despite successful exports in the game-show category, like The Weakest Link or Who Wants To Be A Millionaire?, over the last decade, Britain has consequently turned to Europe to sell its comedy, while North America is increasingly looking to South America, for instance with ABC's dramedy Ugly Betty (2006-10), a remake of Columbian telenovela Yo Soy Betty, la fea (RCN, 1999-2001), to give but one example.

Judging from the scandal around MTV's adaptation of edgy youth-oriented British Channel Four programme Skins, which, in early 2011, faced questions of child pornography laws, the success of The Office US therefore appears as an exception in the new millennium. While having kick-started the Anglo-American collaboration, the programme further seems to illustrate how television is now "simultaneously shaped by the globalization of media economics and the pull of local and national cultures." ${ }^{35}$ For if popular television formats can easily be exported-sometimes leading to a standardization of contents where media industries worldwide use the same idea-such industrial process nevertheless almost systematically implies the adaptation of contents to suit local preferences. Based on a marketing strategy known as 'glocalization, ${ }^{36}$ in the case of comedy, the technique would thus tend to show that humour remains strongly national in the global twenty-first century.

\section{BIBLIOGRAPHY}

Baker, James. Teaching TV Sitcom. London: British Film Institute, 2003.

BBC News. "Royles Cleaned Up for US TV." April 8, 2001. http://news.bbc.co.uk/2/hi/ entertainment/1264199.stm <accessed on 1 June, 2010>

Bianco, Robert. "NBC copy machine misfeeds at “The Office." USA Today, March 23, 2005. http:// www.usatoday.com/life/television/reviews/2005-03-23-the-office_x.htm <accessed on February 24, 2011> 
Bowes, Mick. “Only When I Laugh.” In Understanding Television, eds. Andrew Goodwin and Garry Whannel. London: Routledge, 2001, 131-44.

Briggs, Asa. The History of Broadcasting in the United Kingdom, Golden Age of Wireless, vol. 2. Oxford: Oxford University Press, 1995.

Dickason, Renée. La Société britannique à travers ses fictions télévisuelles : le cas des soap operas et des sitcoms. Paris: Ellipses, 2005.

Eaton, Mick. “Television Situation Comedy.” Screen 19, no. 4 (Winter 1978-1979): 61-89.

Gitlin, Todd. The Whole World is Watching: Mass Media and the Making and Unmaking of the New Left. Berkeley: University of California Press, 1981.

Gladden, Jack. “Archie Bunker meets Mr Spoopendyke: nineteenth-century prototypes for domestic situation comedy." Journal of Popular Culture 10, no. 1 (1976) 167-80.

Hall, Stuart. "Encoding/Decoding." In Culture, Media, Language, Stuart Hall et al., eds. . London: Routledge / Centre for Contemporary Cultural Studies, Birmingham, 2004, 107-117.

Hamamoto, Darrell Y.. Nervous Laughter: Television Situation Comedy and Liberal Democratic Ideology. New York: Praeger, 1991.

Hight, Craig. Television Mockumentary: Reflexivity, Satire and a Call to Play. Manchester: Manchester University Press, 2011.

Howes, Valerie. “Ricky Gervais: From World's Worst Boss to Employee of the Year." Ukula. http:// www.ukula.com/TorontoArticle.aspx?SectionID=3\&ObjectID=1665\&CityID=3. <accessed on May 11, 2010>

Hughes, Sarah. "America is a foreign country; they view things differently there." The Observer, March 29, 2009. http://www.guardian.co.uk/media/2009/mar/29/ustelevision-television $<$ accessed on June 22, 2010>

Jones, Gerard. Honey, I'm Home! Sitcoms Selling the 'American Dream.' Grove Weindenfeld: St. Martin's Griffin, 1993.

Marc, David. Comic Visions: Television Comedy and American Culture. New York: Blackwell, 1989.

Masters, Kim. "British TV Crosses Over the Pond." NPR News: Morning Edition, March 24, 2005. http://www.npr.org/templates/story/story.php?storyId=4558607, <accessed on June 2, 2010>

Miller, Jeffrey. Something Completely Different: British Television and American Culture. Minneapolis: University of Minnesota Press, 2000.

Neale, Steve, Krutnik, Frank. Popular Film and Television Comedy. London: Routledge, 1995.

Newcomb, Horace and Paul Hirsch. "Television as Cultural Forum.” In Television: The Critical View, $6^{\text {th }}$ edition, ed. Horace Newcomb. New York: Oxford University Press, 2006. 561-74.

Ouelette, Laurie. Viewers Like You? How Public Television Failed the People. New York: Columbia University Press, 2002.

Pike, Frank, ed., Ah! Mischief: Writer and Television (London: Faber \& Faber, 1982).

Porter, Laraine. "Tarts, Tampons and Tyrants. Women and Representation in British comedy." In Because I tell a Joke or Two, Comedy, Politics and Social Difference, ed. Stephen Wagg. London: Routledge, 1998, 65-94. 
Rabin, Nathan. "Inventory: Eight Sure-Fire Fiascoes That Unexpectedly Succeeded.” The A. V. Club, March 29, 2006. http://www.avclub.com/articles/inventory-eight-surefire-fiascoes-thatunexpectedl,1532/ <accessed on April 3, 2010>

Robertson, Roland. "Comments on the 'Global Triad' and 'Glocalization”, 'Globalization and Indigenous Culture' Conference, Institute for Japanese Culture and Classics, Kokugakuin University, 1997. http://www2.kokugakuin.ac.jp/ijcc/wp/global/15robertson.html <accessed on March 10, 2011>

Roscoe, Jane, Hight, Craig. Faking It: Mock-documentary and the Subversion of Factuality. Manchester: Manchester University Press, 2002.

Schiller, Herbert I. Mass Communications and American Empire. New York: A. M. Kelley, 1969.

The Office Tally. “Greg Daniels and Rainn Wilson Conference Call.” March 24, 2008. http:// www.officetally.com/greg-daniels-and-rainn-wilson-conference-call <accessed on February 24, 2010>

Timms, Dominic. "US Version of The Office Scores Ratings Victory." MediaGuardian, March 29, 2005. http://www.guardian.co.uk/media/2005/mar/29/broadcasting <accessed on March 23, 2010>

Took, Barry. Laughter in the Air. London: Robson / BBC, 1981.

Waisbord, Silvio. "McTV: Understanding the Global Popularity of Television Formats." Television and New Media 5, no. 4 (2004): 359-83.

Waller, Ed. "When Hollywood killed the Kumars." The Independent, December 9, 2003. http:// www.independent.co.uk/news/media/when-hollywood-killed-the-kumars-576013.html $<$ accessed on June 22, 2010>

Wells, Paul. "'Where everybody knows your name', Open convictions and closed contexts in the American situation comedy." In Because I tell a Joke or Two, Comedy, Politics and Social Difference, ed. Stephen Wagg. London: Routledge, 1998, 180-202.

Wertheim, Arthur. Radio Comedy. New York: Oxford University Press USA, 1979.

Winters, Rebecca. “Television: Doctor Is in... a Bad Mood.” TIME Magazine, September 4, 2005.

http://www.time.com/time/magazine/article/0,9171,1101308,00.html <accessed on February 28, 2011>

\section{NOTES}

1. Jeffrey Miller, Something Completely Different: British Television and American Culture (Minneapolis: University of Minnesota Press, 2000) 2.

2. Also known as TWTWTW or simply TW3, the show used current events to lampoon the establishment, including the Profumo scandal, in 1963, when Secretary of State for War John Profumo's affair with Christine Keeler, the mistress of an alleged Russian spy, was disclosed to the British publish. In turn, the US version poked fun at contemporary political leaders, notably John F. Kennedy and Richard Nixon. First hosted by Elliott Reid, in 1964, NBC's TW3 took advantage of the BBC's decision to cancel the show due to upcoming elections to ask David Frost, the original British presenter, to replace him.

3. A contraction of 'situation comedy,' "the term 'sit-com' describes a short narrative-series comedy, generally between twenty-four and thirty minutes long, with regular characters and 
setting." Steve Neale and Frank Krutnik, Popular Film and Television Comedy (1990; London: Routledge, 1995) 233.

4. See for instance Stuart Hall, "Encoding/Decoding," in Culture, Media, Language, ed. Stuart Hall et al., Culture, Media, Language (1980; London: Routledge / Centre for Contemporary Cultural Studies, Birmingham, 2004) 107-117.

5. Fox's medical drama House (2004- ), starring English actor Hugh Laurie-who notably appeared in BBC1's historical sitcom Blackadder (1983-89)-provides an interesting example in that respect: "After watching hours of casting tapes for the pilot [...], House executive producer Bryan Singer refused to see any more British actors due to their imperfect American accents. 'Luckily Bryan had no idea who Hugh was,' [said] the show's creator David Shore, who played Laurie's audition tape [...] for Singer. 'Bryan said, 'That's what we want, a terrific American actor."' Rebecca Winters, "Television: Doctor Is in... a Bad Mood," TIME Magazine, September 4, 2005.

http://www.time.com/time/magazine/article/0,9171,1101308,00.html <accessed on February 28, 2011>

6. Pierre Desproges, interviewed in Télérama, November 24, 1982.

7. Arthur Wertheim, Radio Comedy (New York: Oxford University Press, 1979) 31.

8. James Baker, Teaching TV Sitcom (London: British Film Institute, 2003) 17.

9. Paul Wells, “'Where everybody knows your name', Open convictions and closed contexts in the American situation comedy," in Because I tell a Joke or Two, Comedy, Politics and Social Difference, ed. Stephen Wagg (London: Routledge, 1998) 191. A notable exception was Beulah (CBS radio, 1945-54; ABC TV, 1950-52), the second US black sitcom after Amos ' $n$ ' Andy.

10. In 1923, the government appointed the Sykes Committee to inquire into the organisation of broadcasting in Britain. Commenting on the potential of the system, the Committee concluded that broadcasting should be defined as a "public utility": "We attach great important to the maintenance of a high standard of broadcast programmes [...] and we think that advertisements would lower the standard." Broadcasting Committee Report (Sykes Report), Cmd. 1951 (London: HMSO, 1923), par. 41.

11. Asa Briggs, The History of Broadcasting in the United Kingdom, Golden Age of Wireless, vol. 2 (1965; Oxford: Oxford University Press, 1995) 118.

12. James Baker, Teaching TV Sitcom (London: British Film Institute, 2003) 19.

13. David Marc, Comic Visions: Television Comedy and American Culture (New York: Blackwell, 1989) 118.

14. 'Kitchen sink drama' is "a rather condescending title applied from the late 1950s onwards in Britain to the then new wave of realistic drama depicting the family lives of working-class characters, on stage and in broadcast plays." Chris Baldick, The Concise Oxford Dictionary of Literary Terms, $3^{\text {rd }}$ edition (New York: Oxford University Press, 2009), 179. On the spirit of 'mischief' encouraged by Hugh Greene during his BBC Directorship, see Frank Pike, ed., Ah! Mischief: Writer and Television (London: Faber \& Faber, 1982).

15. As Laraine Porter observes: "Comic stereotypes which transgress sexual binaries and 'normality' abound in the history of popular carnival and comic performance. In twentiethcentury theatrical farce, radio and music hall, sexual disguise, cross-dressing and sexual innuendo have formed a basis for a substantial proportion of popular British comedy." Laraine Porter, "Tarts, Tampons and Tyrants. Women and Representation in British Comedy," in Because I Tell a Joke or Two, Comedy, Politics and Social Difference, ed. Stephen Wagg (London: Routledge, 1998) 83.

16. "Blighty [is] an informal and often affectionate term for Britain or England, chiefly as used by soldiers of the First and Second World Wars [...]. The term was first used by soldiers serving in India, and is an Anglo-Indian alteration of Urdu bilāyatī 'foreign, European', from Arabic wilāyat, wilāya 'dominion, district'." Elizabeth Knowles, ed., The Oxford Dictionary of Phrase and Fable (New York: Oxford University Press, 2001) 120. 
17. Laurie Ouelette, Viewers Like You? How Public Television Failed the People (New York: Columbia University Press, 2002) 23.

18. Todd Gitlin, The Whole World is Watching: Mass Media and the Making and Unmaking of the New Left (Berkeley: University of California Press, 1981) 256.

19. Horace Newcomb and Paul Hirsch, "Television as Cultural Forum," in Television: The Critical View, 6th edition, ed. Horace Newcomb (New York: Oxford University Press, 2006) 562.

20. Norman Lear quoted in Jeffrey Miller, Something Completely Different: British Television and American Culture (Minneapolis: University of Minnesota Press, 2000) 155.

21. Kerner Commission, Report of the National Advisory Commission on Civil Disorders (Washington, D.C.: U.S. Government Printing Office, 1968).

22. Norman Lear quoted in Mick Eaton, “Television Situation Comedy," Screen, 194 (1978-1979): 80-81.

23. As Darrell Y. Hamamoto explains, however: "Bill Cosby had originally conceived a show [where] he was to have played the part of a janitor and his wife [...] a construction worker." Darrell Y. Hamamoto, Nervous Laughter: Television Situation Comedy and Liberal Democratic Ideology (1989; New York: Praeger, 1991) 136. In addition, see Sut Jhally and Justin Lewis, Enlightened Racism: The Cosby Show, Audiences and the Myth of the American Dream (Boulder: Westview, 1992).

24. Jon Plowman quoted in Sarah Hughes, "America is a foreign country; they view things differently there," The Observer, March 29, 2009. http://www.guardian.co.uk/media/2009/mar/ 29/ustelevision-television <accessed on June 22, 2010>

25. Beryl Vertue quoted in Ed Waller, "When Hollywood killed the Kumars," The Independent, December 9, 2003. http://www.independent.co.uk/news/media/when-hollywood-killed-thekumars-576013.html <accessed on June 22, 2010> The term 'political correctness' was first used to describe "an influential movement on US campuses beginning in the late 1980s [and] appealing to the principle of affirmative action and multiculturalism [...]. It promoted anti-sexist and antiracist speech and behavior codes, which opponents denounced as illiberal." Ian McLean and Alistair McMillan, The Concise Oxford Dictionary of Politics, $2^{\text {nd }}$ edition (Oxford: Oxford University Press, 2003) 414

26. See note 18 of the present article.

27. Maya Forbes quoted in "Royles Cleaned Up for US TV," BBC News, April 8, 2001. http:// news.bbc.co.uk/2/hi/entertainment/1264199.stm <accessed on June 1, 2010>

28. The term 'mockumentary' is commonly applied to fictional films and TV programmes which appropriate the aesthetics of the documentary genre or other reality-based media with the aim of producing parody or satire. For further details, see for instance Jane Roscoe and Craig Hight, Faking It: Mock-documentary and the Subversion of Factuality (Manchester: Manchester University Press, 2002) and Craig Hight, Television Mockumentary: Reflexivity, Satire and a Call to Play (Manchester: Manchester University Press, 2011).

29. The term "circular narrative closure" is borrowed from Mick Bowes, "Only When I Laugh," in Understanding Television, ed. Andrew Goodwin and Garry Whannel (1990; London: Routledge, 2001) 132.

30. Ricky Gervais interviewed by Valerie Howes, "Ricky Gervais: From World's Worst Boss to Employee of the Year," Ukula,

http://www.ukula.com/TorontoArticle.aspx?SectionID=3\&ObjectID=1665\&CityID=3. <accessed on May 11, 2010>

31. Robert Bianco, "NBC copy machine misfeeds at 'The Office'," USA Today, March 23, 2005. http://www.usatoday.com/life/television/reviews/2005-03-23-the-office_x.htm <accessed on February 24, 2011>

32. "Greg Daniels and Rainn Wilson Conference Call," The Office Tally, March 24, 2008. http:// www.officetally.com/greg-daniels-and-rainn-wilson-conference-call <accessed on February 24, 2010> The term "generic discomfort" is borrowed from Shannon Wells-Lassagne, "Crossing the 
Pond: Adapting The Office to an American Audience," paper given at the Contemporary American Television Series: Between Fiction, Fact, and 'The Real' Conference held at Institut Charles V, Université Paris-Diderot, on June 8, 2010.

33. Ted Harbert quoted in Kim Masters, "British TV Crosses Over the Pond," NPR News: Morning Edition (NPR, March 24, 2005). http://www.npr.org/templates/story/story.php?storyId=4558607 $<$ accessed on June 2, 2010>

Nathan Rabin, "Inventory: Eight Sure-Fire Fiascoes That Unexpectedly Succeeded," The A. V. Club, March 29, 2006. http://www.avclub.com/articles/inventory-eight-surefire-fiascoes-thatunexpectedl,1532/ <accessed on April 3, 2010>

34. Nathan Rabin, "Inventory: Eight Sure-Fire Fiascoes That Unexpectedly Succeeded," The A. V. Club, March 29, 2006. http://www.avclub.com/articles/inventory-eight-surefire-fiascoes-thatunexpectedl,1532/ <accessed on April 3, 2010>

35. Silvio Waisbord, "McTV: Understanding the Global Popularity of Television Formats," Television and New Media, 54 (2004): 359.

36. A combination of "globalization" and "localization," the term is used to describe a product or service that is developed and distributed globally, but tailored to match the specifics of a local market. It is said to have been first used by sociologist Roland Robertson, who, in 1997, defined 'glocalization' as "the simultaneity-the co-presence-of both universalizing and particularizing tendencies." Roland Robertson, "Comments on the 'Global Triad' and 'Glocalization," 'Globalization and Indigenous Culture' Conference, Institute for Japanese Culture and Classics, Kokugakuin University. 1997. http://www2.kokugakuin.ac.jp/ijcc/wp/global/15robertson.html $<$ accessed on March 10, 2011>

\section{ABSTRACTS}

In an increasingly 'glocalized' world, the success of NBC's still-running remake of the BBC's The office would seem to indicate the continuing vitality of 'Britcom' adaptations on American network television. Initiated by US producer and comedy writer Norman Lear in the early 1970s, such cross-cultural translation has nevertheless had a long history of hit-or-miss experiences over the decades. Following an analysis of how the early television developments of the situation comedy genre in both countries may have favoured the emergence of different types of sitcom humour, this article will introduce several case-studies of US 'Britcom' remakes so as to map out the socio-cultural specificities at work in the retooling process central to such exchanges from the British to the American television industry.

\section{INDEX}

Keywords: situation comedy, sitcom, Britcom, United States, television, cross-cultural, remake, adaptation, transposition, humour, transferability 


\section{AUTHOR}

\section{AMANDINE DUCRAY}

Amandine Ducray is an Associate Professor in British Studies at the Université Paris Ouest

Nanterre La Défense, France. In 2009, she published Les Sitcoms ethniques à la télévision britannique de 1972 à nos jours : jusqu'à ce que l'humour nous répare.

Université Paris Ouest Nanterre La Défense 